\title{
地震火災危険分析システムの適用に関する研究 *
}

\section{A Study on The Application of The Fire Risk Analysis System under A Great Earthquake *}

\author{
二神 透**, 和田 修司 ${ }^{* * *}$ \\ by Tohru FUTAGAMI, Shuji WADA
}

\section{1.はじめに}

地震大国であり、また、依然として木造住宅が密 集する我が国における地震火災の危険性は、大きな 务威である。過去の事例より、地震規模が大きい場 合、木造建物の倒壊等に起因する同時多発火災の危 険性が指摘されている。さらに、倒壊建物による道 路閉塞や、消火栓、消防水利の破損による消防力の 低下や、強風等の悪条件が火災の延焼危険性を大き く助長している。この典型的な事例は、1923年の関 東大震災に見られ、東京旧 5 区で 130 件の火災が発 生し、60の合流火災となり、10万人が焼死した。戦 後の都市直下型地震に着目すると、1948年の福井地 震では、市内の建物の全壊率は $80 \%$ に及び、 2,000 軒以上の建物が焼失した。また、1995年の阪神・淡 路大震災では、風速が比較的小さかったにも関わら ず、消防力の低下により、100 件以上の同時炎上火 災が発生し、7,000軒もの建物が焼失している。こ れらの事実は、大震時には、日本の都市が同時多発 火災の危険性を依然として内在していることを強烈 に示している。この同時多発火災の特徴は、上述し たように出火点が複数であり、それらが木造密集市 街地で発生すれば、火災が拡大して合流火災とな り、消防力の対応を阻害すると同時に、避難路の確 保が困難となるため、人的・物的被害を拡大する点 にある。

これらの火災による被害を軽減するための対策と しては、1）大震時の出火を抑制する。2 ) 消防力 により延焼火災を制圧する。3) 具体的な延焼被害

\footnotetext{
・ キーワーズ：防災計画、計画情報、シミュレーション

**正会員、学博、愛媛大学工学部環境建設工学科

（テ790-8577 愛媛県松山市文京町3番、

TEL089-927-9837、FAX089-927-9837)

.**学生員、愛媛大学大学院理工学研究科土木海洋工学専攻
}

(同上)
の算定と対応策の検討、の 3 つのフェーズによる総 合的対策が有効であり、これらに関する研究は、従 来より幅広く行われている。

1）について、水野らは、早くから過去の大地震 の出火、建物被害等の調查報告等を整理し、出火の 性質を明らかにし、地震時の出火回帰式を提案して いる11。しかし、近年、都市の多様化に伴い建物構 造や、出火源の様相も大きく変化しており、阪神. 淡路大震災でも従来からは予想されない出火源も報 告されている2)。2）について、保野らは、現状の 消防力の基で、建物火災と有効消火注水量について の検討を行っている3)。3）について、種々の延焼 速度式、シミュレーション・モデルが提案され被害 想定に基づく対策が提案されている4),5)。しかし、操 作性、視覚性を具備したダイナミックなシミュレー ション・システムを用いたアプローチはほとんど見 られない。

本研究では、都市の酎火構造に着目し、例え同時 多発による延焼火災が発生しても、ブロック内で延 焼をくい止め、他のブロックへの拡大を阻止するブ ロック化計画を取り上げ6)、著者らが開発を行って いる火災延焼シミュレーション・システムを基礎と した、地震火災危険分析システムの構成 6 (7), 7) ,8) と防 災計画への適用についての検討を試みる。そのため に、広域市街地の地震火災の危険性を視覚的に提示 可能な火災延焼シミュレーション・システムを構成 することを考える。具体的には、地震規模と地盤、 建物の密集度を説明変数とする出火件数算定モデル を基礎とした、メッシュの出火点設定モデル6) 用 いて、地震火災危険分析システムを構成する。ただ し、大地震時の消防力ついては、阪神・淡路大震災 事例でも見られたように十分には期待できないと仮 定して考慮していない。つぎに、本システムを用い て、金沢市への適用を試み、地震火災に対する脆弱 
な地域を検討し、河川・道路・緑地・鉄道等の都市 の持つ地理的延焼阻害要因を分析する。そして、こ れらの結果に基づくブロック化計画を策定し、焼失 面積を特性値として、火災延焼シミュレーション・ システムによる計画の評価を試みるとともに、住民 の防災意識が初期消火率の向上につながると仮定 し、ブロック化と初期消火率の相互効果についても 検討を行う。

\section{2. 地震火災危険分析システムの構成}

本研究では、図 1 に示す地震火災危険分析システ ムを構成した。このシステムの入力系としては、航 空写真からのメッシュ・マップ作成システム、地震 規模、地盤種別、木造建物数による出火地点の設定 システム、初期消火率、風向・風速の設定システム がこれにあたり、出力系としては、地震火災危険提 示システムがあたる。

まず、メッシュ・マップ作成システムについて説 明する。基本的には、対象とする地域の航空写真を 用いて、ドット・カウンター法により都市構造デー 夕となるメッシュ・マップ・デー夕を作成する。そ の際、メッシュ・マップの属性は、都市構造物の占 有率に応じて、可燃メッシュ、酎火造メッシュ、緑 地メッシュ、空地メッシュの 4 種類に分類する。可

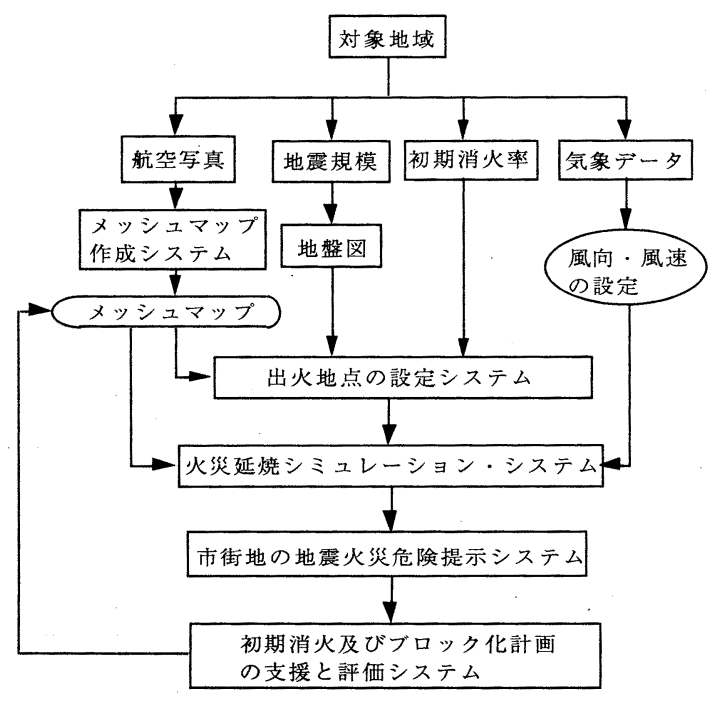

図1地震火災危険分析システム
燃メッシュについては、建ぺい率、建物種別の混成 比等のデータを入力する。

一方、緑地メッシュについては、樹木高さと樹木 密度のデータを入力する。この緑地メッシュは、緑 地の構成（配置密度、緑地高さ）とダイナミックに 延焼する火炎領域との物理的位置関係、輻射受熱量 によって阻害要因または、可燃要因と評価が分かれ る。本システムでは、緑地防火効果をモデル化し、 シミュレーション・システムに拡張化して、それら の防火効果の有無をダイナミックに判定可能なシス テムを構成している7)。

つぎに、出火地点の設定システムについて説明す る。基本となる地震時出火炎上モデルは、地震の規 模、地盤の種別、木造建物数をパラメータとしてい る。地震動の強さについては、地震の規模を想定す ればよい。地盤の種別については、対象地域の地盤 地図を基に、堅い地盤、中間の地盤、軟弱地盤の 3 種類に分類する。そして、これらのデータを都市構 造メッシュ・マップと同様に、地盤メッシュ・デー 夕として採取する。これらのパラメータを用いて、 地震規模と地盤、建物の密集度を考慮した出火地点 メッシュの算定が可能となる。

最後に、初期消火率の取り扱いについて述べる。 初期消火率と震度の関係については、震度 7 以上で は、24\%弱であることが知られている4)。本研究で は、初期消火率は、防災啓蒙の普及と消防力の整備 によって向上すると仮定し、外生的に与えることと する。本地震火災危険分析システムの特徵は、上述 したように、さまざまなシナリオを想定した延焼危 険性を視覚的に提示可能である点である。また、マ ルチウィンドウを用いた計画支援型の情報システム を構築していることもあげられる。例えば、対象地 域の航空写真や地盤図の表示、都市構造メッシュ・ データの数值情報をシミュレーション画面と同時に 提示可能な構成としている。これらの情報は、具体 的なブロック化計画を策定する際に有用であり、ま た、基本計画の定量的な評価と迅速なフィードバッ クを可能とする。

\section{3．金沢市への適用事例}

\section{（1）金沢市の現況}


金沢市は、日本海側に位置し1996年現在、人口 458,000人の北陸地方の中核都市である。歴史的に は、17世紀中頃に、城下町としての体裁が整い、現 在でも細街路網の基本的な形の変化はない。既成市 街地の地形は、卯辰山、小立野台地、寺町台地とい う 3 つの丘陵・台地と浅野川、犀川の 2 つの河川に よる起伏ある構成が大きな特徵である。これらの地 形が、起伏に富む金沢固有の市街地環境と、水と緑 豊かな景観を形成している。

金沢市は、1968年 4 月に、「金沢市伝統環境保存 条例」を制定した。これは歴史的景観を持つ市町村 が制定した独自の保存条例としては初めてのもので ある。1989年には、市民参加、総合的かつ計画的な 景観づくりを目的として、「金沢市伝統環境保存条 例」を継承・発展させた「都市環境条例」を制定 し、新たに「近代的都市景観創出区域」を指定して いる。

金沢市の人口は、1970 1995年の 25 年間で 362,000 人から 454,000 人と、1.25倍に増えてい る。1975～1980年の年間増加率は、1.7\%を記録し ているが、1990 1995年の年間増加率は、0.5\%と 低い值となっている。一方、図 2 のDID面積の推移 を見ると、1970年から 25 年間で $25 \mathrm{~km}^{2}$ から $56 \mathrm{~km}^{2}$ と 2 倍強も増加している。近年の傾向は、DIDの1990 1995年の伸び率が $1.6 \%$ と比較的高い数値を示して いる。図 3 に、金沢都市圈のDIDの分布の面的推移 を示す。この図より、金沢市では、年々DID地区が 大きく増加しており、都心部を中心にして特に西・ 南部方面に増加していることが分かる。ちなみに、

$\left(\mathrm{km}^{2}\right)$

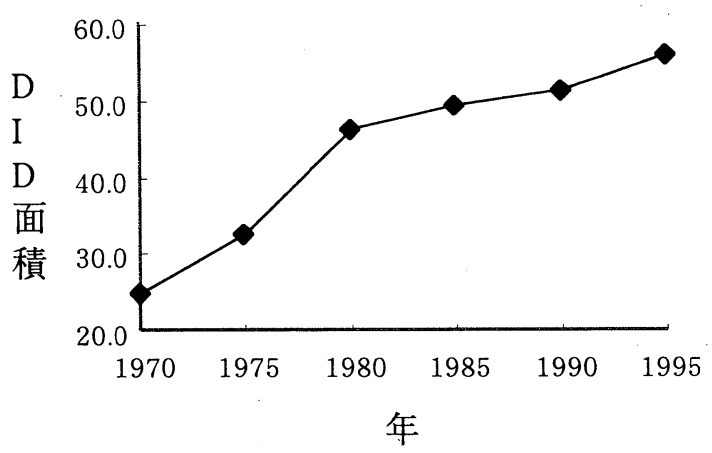

図 2 金沢市におけるD | D面積の推移
これらの地域は、沖積層の地盤の弱い地域であり、 地震時には家屋の倒壊危険性が高いと予測される。

\section{（2）金沢市の地震火災分析}

まず、対象地域となる金沢市のメッシュ・マップ を作成する。そこで、金沢市中心部の航空写真上に $4 \mathrm{~km}$ 四方を対象として、単位メッシュ長を $50 \mathrm{~m}$ とし た $80 \times 80$ のメッシュを掛ける。そして、ドット・ カウンター法により、メッシュ内の構造物の占有率 を判定し、図1のサブシステムであるメッシュ・ マップ作成システムを用いて当該地域のメッシュ・ マップを作成する。

図 4 に、一連の手順によって作成された都市構造 メッシュ・マップを示す。この図より、犀川・浅野 川周辺に市街地が広がっていること、それらの西側 は、比較的オープン・スペースの占有率が高いこと が分かる。しかし、図 3 の金沢市の DID 分布の推移 で述べたようにここれらの地域は人口増加傾向が見 られ、将来的には建物が密集し、地震火災危険性が 高くなると予測される。つぎに、地盤メッシュ・ マップを作成するために、石川県の作成した地盤地 図を使用して、地盤の強さを、堅い岩盤、中間の地 盤、軟弱地盤の 3 種類に分類した。これらのデー夕 を基に、図 5 に示す地盤メッシュ・マップを作成し た。

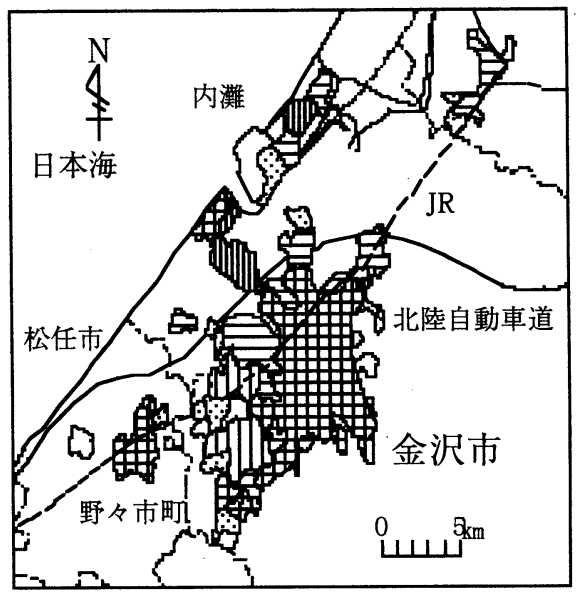

囲 1970 盂 1975 目1980

国 $1985 \quad$ Q. 1990

図 3 金沢市におけるD । D分布の推移 
この地盤メッシュ・マップと図 4 の都市構造メッ シュ・マップを比較すると、市街地中心部は中間あ るいは、硬い地盤の上に立地しており、メッシュ・ マップの南側の寺町から西側の増泉の地盤も比較的 良いことが分かる。一方、鉄道を挟んだ市街地西部 の地盤や、浅野川、犀川沿いの地盤は軟弱であるこ とが分かる。

気象データである風向・風速については、1995 年の金沢地方気象台の統計データ9)を使用し、風向 は、卓越する南西の風を設定した。風速について は、日本海側特有のフェーン現象に代表される強風 時を想定して $10 \mathrm{~m} / \mathrm{s}$ をえる。そして、本適用事例 では、地震規模を 1948 年に発生した福井地震のマ グニチュード 7.3 を想定した。

出火点は、出火点設定システムによって、地震規 模、地盤と木造建物の密集度をパラメータとして確 率的に与えられるため、シミュレーションを実施す るたびに出火点の発生場所は異なる。そこで、一 応、単位時間を 5 分とする 100 回の繰り返し実験を 実施し、180 分後の焼失面積を特性值とした。この 一連のシミュレーション結果を分析した結果、最大 焼失面積は $135.5 \mathrm{ha}$ となり、この場合の出火点数は 7 箇所であった。それらの出火点箇所と地盤メッ シュ・マップを対応させると、沖積層が 2 箇所、中 間の地盤が 4 箇所、硬い地盤が 1 簓所となってい
る。地理的には、住宅が密集している犀川付近で4 箇所、台地で 2 箇所、浅野川近辺で 1 箇所発生して いる。

図 6、7に、シミュレーション実験の結果、最大 焼失面積となった 30 分後、180 分後のアウトプッ ト・マップをそれぞれ示す。図 6 より、犀川周辺の 木造密集市街地から複数の出火点が発生しているこ とが分かる。これらの出火点は、30分後には南西の 風方向にある程度の規模を持ち延焼拡大し、合流火 災の様相を呈していることが分かる。図 7 の 180 分 後のシミュレーション結果を見ると、これらの同時 多発火災は合流し、4つの大規模な市街地火災に なっていることが分かる。そして、このまま延焼が 進行すると、これらの火災はさらに合流し、市街地 の殆どが焼失することが予想される。ここで、実施 した100回のシミュレーション実験結果の平均焼失 面積を分析すると、180 分後の平均焼失面積は $36.9 \mathrm{ha}$ となり、平均出火点数は 2.5 筒所となった。 出火点数は異なるが、昭和 51 年の山形県酒田大火 と焼失面積を比較すると、酒田大火の焼失面積が、 $22.5 \mathrm{ha}$ でることを考えると、かなりの規模の火災 であることが推測されよう。

\section{（3）金沢市のブロック化計画と評価}

本節では（2）の金沢市の地震火災危険分析に基

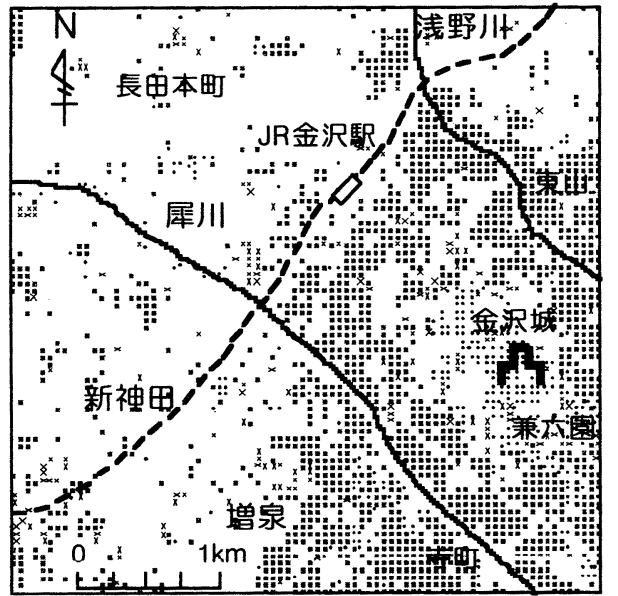

空地メッシュ

圈可燃メッシュ
凶耐火造メッシュ

回緑地メッシュ

図 4 都市構造メッシュ・マップ

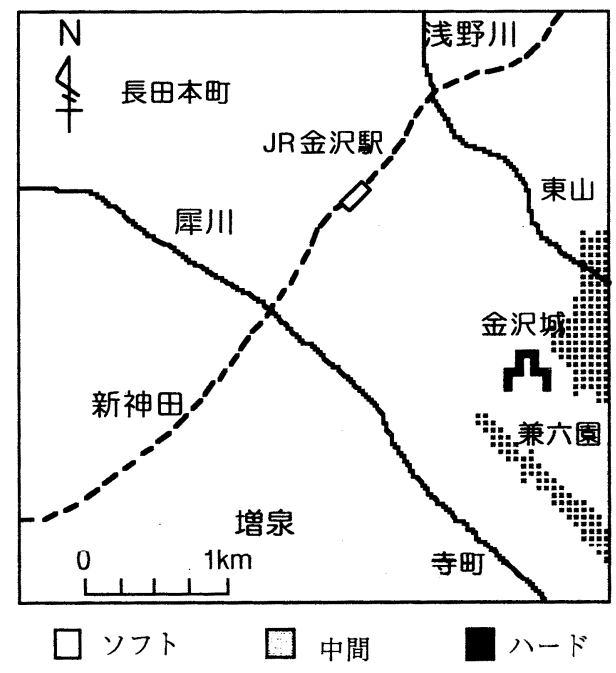

図 5 地盤メッシュ・マップ 
づて、延焼阻害要因となる河川・鉄道・空地・緑 地等を有機的に組み合わせることによる戦略的な市 街地のブロック計画とその評価を試みる。そのため に、シミュレーション実験結果を基に延焼拡大危険 性の大きな箇所や火災が合流する箇所を詳細分析し た。その結果、鉄道、犀川は延焼遮断効果が認めら れたが、浅野川では、鉄道と交差する地域から南側 に100m下がった地域から浅野川を越えて東山側へ の延焼危険性があることが明らかになった。また、 シミュレーション結果より、姩川・浅野川と鉄道で 囲まれる金沢城を中心とする旧市街地の延焼危険性 が特に高く、浅野川から東山、犀川から寺町、増泉 にかけても同様に延焼危険性が高いことが明らかに なった。一方、河川・鉄道以外の延焼阻害要因であ

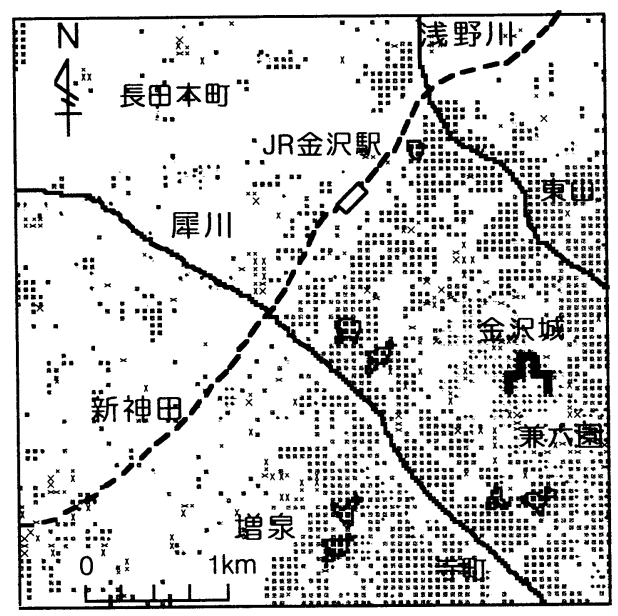

$\begin{array}{ll}\text { 空地メッシュ } & \text { 区 耐火造メッシュ } \\ \text { 可燃メッシュ } & \text { 緑地メッシュ }\end{array}$

図6 シミュレーション結果 (30 分)

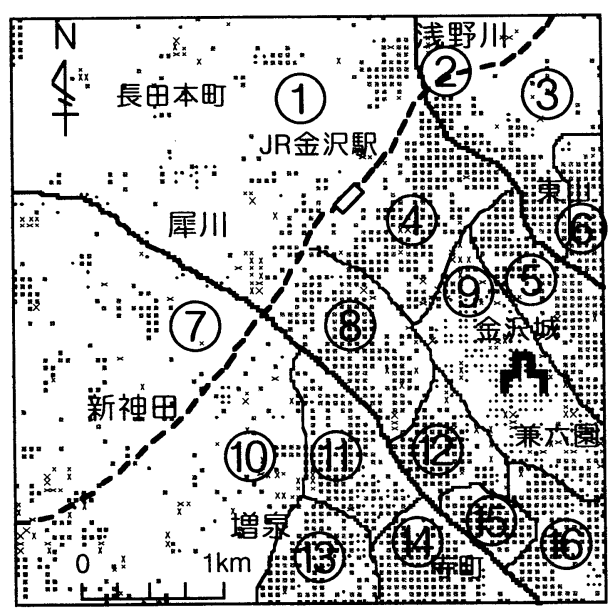

$\square$ 空地メッシュ

囚 耐火造メッシュ

可燃メッシュ

回緑地メッシュ

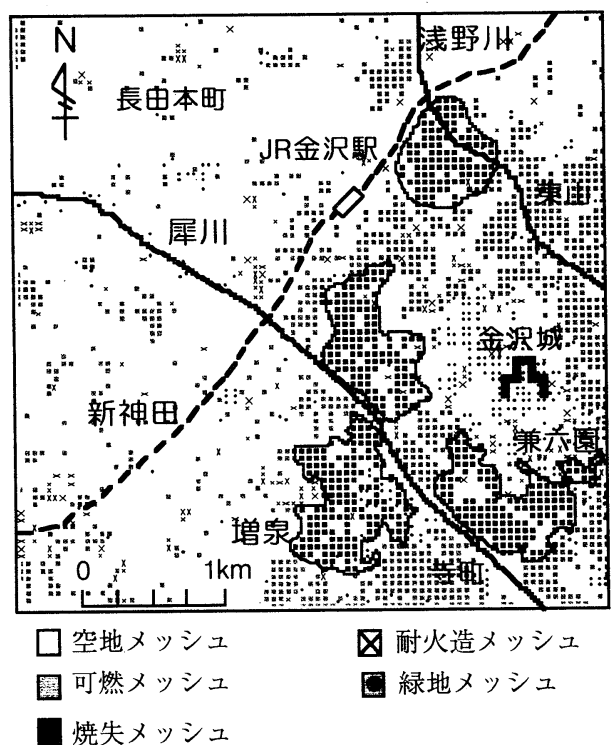

図7 シミュレーション結果 (180 分)

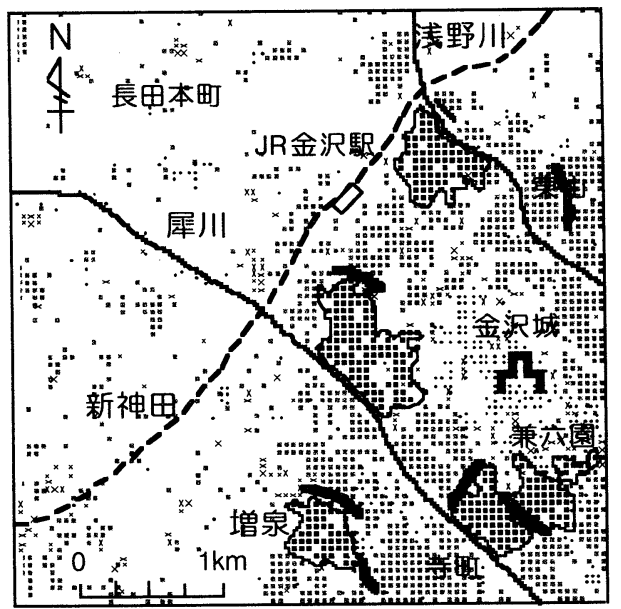

空地メッシュ

囚 耐火造メッシュ

图可燃メッシュ

緑地メッシュ

焼失メッシュ

一ブロック化を行った箇所

図 9 ブロック化の効果（180分） 
る空地・緑地によってブロック化されている地域も 明らかになった。

以上の分析を基に、ブロック化の基本戦略を計画 する。シミュレーション実験の結果、図 8 の、(1)、 (2)、(5)、 (7)、9、(10の地域は、河川・鉄道・空地・ 緑地の阻害要因によってブロック化されていること が判明した。これら以外の地域については、航空写 真や、都市構造メッシュ・マップの数值情報を表示 し、隣接する都市構造物や地形に合わせて、道路幅 員の拡大といったオープン・スペースや、酎火建 物、緑地を配置させ、なるべく少ないメッシュ属性 の変更で数多くのブロック化ができるように配慮し た。その結果、図 9 の太線で示す箇所をブロック化 対象として、全体で 40 メシュ（10ha）の変更を 行い、市街地を 16 のブロックに分割した。その内 訳は、オープン・スペースが、15メッシュ (3.75ha)、 耐火建物 13 メッシュ (3.25ha)、緑地が 12 メッシュ (3.0ha)である。なお、新たに配置した緑地メッシュ の構成は、高さ $6 \mathrm{~m}$ の常緑広葉樹を密度 $60 \%$ で想 定した。

つぎに、本ブロック化計画の効果を定量的に把 握・検討するために、まず最大の焼失面積を与えた ケースの出火点を想定して、シミュレーション実験 を行った。その結果を図 9 に示す。図 9 より、ブ ロック後のシミュレーション結果を見ると、耐火建 物、オープン・スペースによって、基本戦略によっ てブロック化された部分で焼け止まっていることが 分かる。また、緑地メッシュに着目すると、詳細分 析より、配置した緑地メッシュの全てが延焼阻害要 因としての効果が認められた。これについては、本 適用事例で用いた単位メッシュサイズが $50 \mathrm{~m}$ と大 きいため、想定した $50 \mathrm{~m}$ 四方の緑地は、このような 大火でも十分に延焼阻害効果があると言える。しか し、実際、このような規模の緑地を市街地に多く配 置することは困難であるため、緑地については詳細 なメッシュ・デー夕を用いて分析・検討する必要が あろう。このブロック化案の効果を具体的に見るた め、図 10 にブロック化前後の焼失面積の推移を比 較した。この図より、本ブロック化案では、焼失面 積が時間の経過とともに大幅に滅少しており、180 分後では、135.5ha から 89.8ha と約 $33.7 \%$ 隇少 していることが分かる。以上は、最も危険なシナリ

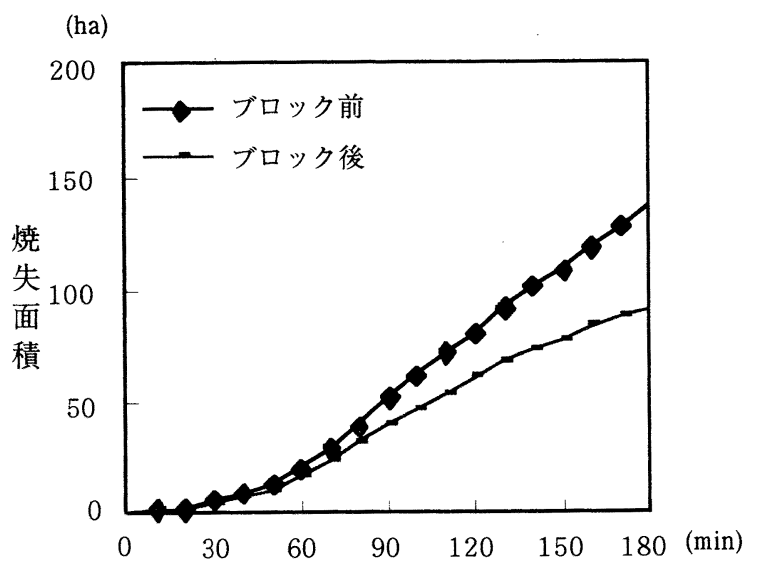

図 10 焼失面積の比較

オを想定した場合の分析である。つぎに、本ブロッ ク化案の効果の評価指標として平均焼失面積の比較 を行った。その結果、180 分後の平均焼失面積は、 $36.9 \mathrm{ha}$ から $16.6 \mathrm{ha}$ と約 $55 \%$ も減少することが分 かった。

今回の事例では、複数の代替案が想定されるブ ロック化計画案の一つについて、焼失面積を特性值 とする分析・評価を行ったが、今後、計画のコスト 制約など実行可能性の観点から複数の代替案につい ても評価・検討する必要があろう。

\section{（4）地震時における初期消火の効果分析}

地震時の初期消火率は、地震の規模に因るものが 大きいが、住民の防災意識の向上や消防力の増強に より、今後、初期消火率が大きく改善されると考え られる。本節では、初期消火力とブロック化の $2 つ$ の戦略を組み合わせることによる都市の耐火性への 効果について分析を試みる。まず、ブロック化の前 後と初期消火率を $10 \% 、 20 \%$ と変化させ、特性值を 同じく180分の焼失面積とするシミュレーション実 験を 100 回実行し、それらの平均焼失面積を算定し た。それらの結果を、表1、2にまとめる。

まず、表 1 よりブロック化前では、消火率10\%で 平均焼失面積が $36.9 \mathrm{ha}$ から、31.2ha と約 15\% 減少 し、消火率 $20 \%$ では、約 $23 \%$ も減少することが分 かる。これより、消火率の向上に伴い、都市の耐火 性は大きく向上する。一方、表 2 よりブロック化と 初期消火率による焼失面積の相乗減少率の差に着目 
表1 初期消火率と焼失面積

の関係（ブロック前）

\begin{tabular}{|r|r|l|}
\hline 消火率 & 平均焼失面積 & 減少率 \\
\hline $0 \%$ & $36.9 \mathrm{ha}$ & - \\
$10 \%$ & $31.2 \mathrm{ha}$ & $15.4 \%$ \\
$20 \%$ & $28.6 \mathrm{ha}$ & $22.5 \%$ \\
\hline
\end{tabular}

表2 初期消火率と焼失面積 の関係 (ブロック後)

\begin{tabular}{|r|r|r|}
\hline 消火率 & 平均焼失面積 & 相乗減少率 \\
\hline $0 \%$ & $16.6 \mathrm{ha}$ & $55.5 \%$ \\
$10 \%$ & $14.6 \mathrm{ha}$ & $60.9 \%$ \\
$20 \%$ & $14.1 \mathrm{ha}$ & $62.3 \%$ \\
\hline
\end{tabular}

すると、初期消火率 10\%では 5.4\%、20\%では 6.8\% となっている。これらの数值は、ブロック前の初期 消化率による減少率と比較すると、相対的に小さい 値となっている。この理由としては、ブロック化前 の市街地は、連続可燃領域が広範であるため、消火 率の向上 (出火点の減少) が延焼の拡大に大きく寄 与する。一方、ブロック化後では、出火点が減少し ても、ブロック内の延焼に留まるため、想定した消 火率では大きな焼失面積の差となって表れてこな い。このことは、逆に言えば、本事例で想定したブ ロック化の有効性をある程度示唆していると言えよ う。

これらの結果より、少なくとも都市のブロック化 と初期消火率の戦略を組み合わせることが、都市の 耐火性の向上に寄与することを示唆することができ た。すなわち、都市の耐火性を高めるためには、ブ ロック化地域レベルで具体的な地震火災対策を考え ることが有効であると言えよう。ただし、本ブロッ ク化案は、都市の酎火構造のみに着目しており、コ スト制約や都市計画的な観点については考慮してい ない。今後、ブロック化計画の実行性を考える上 で、れらの観点からの評価法についても検討を行 う必要があろう。

\section{4. おわりに}

本研究では、まず地震火災の危険性をできるだけ 具体的に提示するために、地震規模、地盤特性、木
造建物の密集度を考慮した出火炎上モデルを基に、 地震火災危険分析システムを構成した。そして、緑 地、オープン・スペースといった延焼阻害効果モデ ルをシミュレーション・システムに拡張化し、都市 のブロック化計画支援システムを構成した。そし て、本システムを金沢市に適用した結果、地震火災 の延焼拡大の危険性を時間の経過に従ってダイナ ミックかつ視覚的に提示できることや、ブロック化 計画の策定·評価のフィードバックが容易に実行可 能であることを提示することができた。最後に、初 期消火力を考慮したシミュレーション実験を実施し た結果、都市のブロック化と初期消火率を高めるこ とが、都市の耐火性の向上に大きく寄与することを 示唆することができた。

今後の課題としては、小規模な公園や緑地、オー プン・スペースの配置といった詳細なブロック化を 支援するシステムの開発を行う必要があろう。その ためには、GISによるデジタル地図情報を用いたミ クロ・シミュレーションへのシステムの拡張化が考 えられる。また、GISを用いてシミュレーションの 入力系である、都市構造デー夕、および地盤デー夕 の自動採取化を行い、情報の効率化・精緻化を計り たいと考えている。以上は、データ入出力系の課題 であるが、多様化する出火点設定モデルや、今後増 強が期待できる消防力モデル、混成市街地における 延焼速度式モデルの整合性についても今後検討した いと考えている。

〈参考文献〉

1) 水野弘之、堀内三郎：地震時の出火率と住家全壊 率の関係について、日本建築学会論文報告集、 247, pp.101-110, 1976.

2)平成 7 年兵庫県南部地震被害調査報告（速報）、 建設省建築研究所、1995.

3) 難波義郎·保野健治郎-西谷忠彦・松岡秀男: 地 震時火災を考慮した消防計画、土木学会第 51 回 年次学術講演会、pp.106-107, 1997.

4) 日本火災学会編：火災便覧、共立出版、1997.

5) C.Scawthorn、山田善一、家村浩和、小林正美： 都市における地震火災危険度の予測に関する研 究、日本建築学会論文報告集、313, pp.138-144, 1982. 
6) 木俣 昇、二神 透：広域火災シミュレーショ ン・システムによる地震火災危険の分析、土木学 会電算機利用に関するシンポジウム [査読] 論文 集 13, pp.131-138, 1988.

7)二神 透、木俣 昇: 防災緑地網整備計画のため の火災延焼シミュレーション・システムの拡張化 に関する基礎的研究、土木計画学研究・論文集、 No.12, pp.151-158, 1995.

8) 二神 透、木俣 昇:シミュレーションによる地 震時市街地火災の延焼阻害要因の分析、第 1 回都 市直下型地震災害総合シンポジウム論文集、 pp.261-264, 1996.

9) 金沢市統計書：金沢市都市政策部情報統計課編、 1996.

\section{地震火災危険分析システムの適用に関する研究}

本研究では、地震時の同時多発火災に対する都市防災計画を推進するために、できるだけ具体的に地震火災の危険 性を提示可能とするシミュレーション・システムの開発を行った。本システムを金沢市へ適用した結果、大規模地震 時の同時多発火災の危険性を、時間の経過とともに、ダイナミックに提示することができた。この結果を踏まえて、 耐火建物や緑地、オープン・スペースなどを有機的に構成し、延焼の拡大を阻害するブロック化計画を提案し、計画 の有効性を視覚的かつ定量的に示した。さらに、ブロック化と初期消火率を組み合わせることによって、焼失被害が 大きく低減することを示唆することができた。

\section{A Study on The Application of The Fire Risk Analysis System under A Great Earthquake \\ by Tohru FUTAGAMI, Shuji WADA}

As one of measures, a burning interception zoning plan with open spaces and green spaces is proposed. But, because of missing a system to support the concrete planning, the plan is not carried out. To solve such problem, manager, planner, citizen should recognize how dangerous is the earthquake in the region. For that purpose, we have developed a fire spreading simulation system with visual character, and applied the system to urban disaster preventive problem. In this paper, through a case study, we show the system is effective to recognize fire spreading risk, and is available to support the prevention of disaster planning. 